\title{
Forgotten people?
}

Poverty, Risk and Social Security in Indonesia

Many of the people who are described in this book can be called poor - living below or close to the official Indonesian poverty line - and are living in a moreor-less continuous state of insecurity. Poor people however do not stand alone, but search out and receive - directly or indirectly - support from others. Moreover, they are not always 'frozen' below or close to the poverty line since poorer and richer periods might alternate as a result of seasonal fluctuations in income, lifecycles and alternating periods of misfortune and relative prosperity. Clearly, the poor described here are not living in isolation, but need and use other individuals and institutions to secure their living, access to resources, to gather wealth and status and to provide support in times of need. The book aims to understand these relational aspects of poverty and everyday responses of people living on the margins of society when they are confronted with misfortune and major and minor crises in their everyday lives. It deals with the many ways in which people try to secure their livelihoods over time, directly through their own efforts, or indirectly through support from others - often this locally organized social security is arranged in opposition to the state rather than with its support. In this way, it aims to overcome static approaches to poverty which tend to focus primarily on single and often individualistic elements such as income, poverty lines, material wealth and vulnerability.

A key feature of this book is its central aim to capture diversity. Diversity in poverty and livelihoods, in social security arrangements, in capabilities and networks, in risk-taking strategies among 'the poor', a category much more diverse than generalized statements would suggest. The actions and responses of poor people of different social economic backgrounds, occupations, ages and genders vary greatly. Central to this book is the idea that people follow diverse trajectories guided by individual and cultural preferences that are shaped within structural boundaries, which I call styles. As we have seen in Chapter 4, the concept of style offers an alternative to poverty studies focussed primarily on incomes and assets as well as to structural approaches which emphasise structural inequalities and the adverse consequences of capitalism and globalisation. Styles are both empirically recognizable as analytically distinct. By its focus on styles or pathways, this book offers a new conceptual way to deal with diversity in vulnerability and poverty. At the same time it criticises populist and neoliberal approaches to poverty which over-emphasise the capacity of poor people to change their lives on their own. The concept of style

(C) GERBEN NOOTEBOOM, 2015 | DOI 10.1163/9789004282988_010

This is an open access chapter distributed under the terms of the Creative Commons Attribution-

Noncommercial 3.0 Unported (CC-BY-NC 3.0) License. 
integrates strategic and structural dimensions of making a living and securing support at a daily basis.

This book thus takes the middle road between studies focussing on the agency, capabilities and opportunities of the poor and critical approaches which emphasise structural inequality, adverse incorporations into the capitalist system and the negative effects of structural power differences. First, it highlights the material basis of poverty and the resource base and livelihoods of peasants and migrants and the diversity found within the livelihoods and the reportoires of mutual help and social assistance. Second, it describes the different combinations people make in linking their livelihoods to mutual relationships of support, social security arrangements and institutions of mutual help to show opportunities for social protection and room to manoeuvre for poor people living under adverse conditions. And third, it describes and analyses the intricate interplay of structure and agency, individual survival and social protection, individuals vis à vis the state over time and space.

\section{Forgotten People? The Case of the Madurese}

The story of the Madurese in the new Indonesia is largely a story of a changing Indonesia seen from below. The Madurese, as an ethnic group, are socially, culturally and economically excluded from mainstream developments in Indonesia. The Madurese belong to the poorest ethnic groups in Indonesia; they are underrepresented in the government bureaucracy and the higher ranks of the army and the police, they are relatively poorly educated and often referred to in negative terms such as unrefined, unreliable and uncivilized and are to be found in low-paid, dirty and manual jobs (De Jonge 1995, 2012, Niehof et al. 2005, Retsikas 2007:187, Smith 2011, Stenross 2011). Investigating Madurese making a living in modern Indonesia largely means looking at Indonesia from its fringes.

The lives of Madurese described in this book are stories of people dealing with poverty, risk, social exclusion and threats of violence. It shows the intricacies, insecurities and ambiguities of people making a living through a turbulent decade (1997-2009). At the same time, it is a dynamic story of people taking chances, seeking and creating forms of social protection and of active engagement in new opportunities in the frontier areas.

During the last decade of Suharto's rule and the years of transition that followed, the relatively poor and lowly educated Madurese have not fared well. They have been confronted with ethnic violence (Davidson and Kammen 2002, Van Klinken 2006), social exclusion, increasingly negative stereotyping (De Jonge 
and Nooteboom 2006), a deteriorating rural resource base (Smith 2011, Stenross 2011:18-19) and a decrease in favourable migration opportunities (Nooteboom 2008, Wilson 2011:251).

The Madurese are among the least educated groups in Indonesian society with one of the highest illiteracy rates (BPS 2011, Jones 2001:70, Minza 2012:6769 ). Increasingly, a good education is one of the major assets in the new Indonesia, and development plans are increasingly oriented towards rapid economic growth to be achieved through industrial and infrastructural, mostly urban, development, resource extraction in frontier areas, industrial agriculture, mining and palm oil development and boosting export sectors. If Madurese do work in these sectors, it tends to be in the lower and unregulated echelons of society and, as unskilled workers, they occupy low paid jobs. Moreover, as described in the first part of the book, Madurese living in rural East Java tend to have been left behind in this process. As a relatively neglected group, they represent other categories of rural poor people in Indonesia.

Changes such as decentralization, liberalization, increased natural resource extraction and a shift in the national development focus have led to major changes in agricultural policy (Fuady 2012, McCarthy et al. 2012). After the fall of Suharto, agricultural policies, previously oriented towards the rural masses in Java and Madura, disappeared from the political agenda, and rural policies have turned into schemes of social protection, consumption subsidies and poverty eradication. The slogan: 'Under Suharto, life was much better for us', often to be heard among Madurese small farmers in East Java and among poor migrants in Kalimantan, seems to be true for most Madurese. They lost their relatively privileged position and now, while others are able to prosper, Madurese livelihoods and poverty are stagnating, probably because they tend to live in rural areas (Suryadarma et al. 2006:20). It was also apparent that more research was needed to gain a better picture of this phenomenon and to gather comparable and quantitative data. Migrants with poor and less privileged backgrounds, such as Madurese and people from Eastern Indonesia (NTT) and Papua, face relative stagnation or even deteriorating positions as a direct or indirect effect of these changes (De Jonge 2012, Rachman et al. 2009, Suryahadi and Sumarto 2003, Vel 2001). Are these categories of people what Tania Li (2009) calls surplus people?

In an attempt to understand the socioeconomic position of Madurese in Indonesia today, as well as the diverse old and new forms of poverty and the possible pathways out of poverty, it is important to look at some plausible explanations for their relative exclusion, marginalization and distinctiveness. The answers lie in a combination of the analysis of structural processes of poverty and exclusion such as described in Hart et al. (1989), Hill et al. (2011) and 
as a consequence of the Will to Improve ( $\mathrm{Li}$ 2006) and in studies on agency and creativity such as in many livelihood studies or actor-oriented approaches Long (2001). A close ethnographic look reveals both the power of structures of exclusion and the capability of individuals and groups to make a minor difference at a daily basis. It also helps to explain who some people are successful in coping with difficulties or as a migrant, while others fail and remain trapped in cylces of debt and poverty. Although socially excluded as a social group in the nation of Indonesia, often forgotten or overlooked, probably surplus to global capitalism (Li 2009), individual Madurese show a 'knack for life' (ScheperHughes 1992:446), creativity, endurance, and a persistent will to succeed.

How do the livelihoods of the Madurese in East Java and Samarinda appear and how do they compare with those of other ethnicities and classes? If we consider the mixed experiences of Madurese on leaving Madura as settlers (Krajan, Bondowoso), migrants (Samarinda) or seafarers (Stenross 2011), can we even speak of a shared Madurese culture? What is the role of the state and social safety nets in the new Indonesia? Given the absence of large state-organized welfare schemes, how do Madurese organize social security and welfare among themselves, sometimes stretching over long distances?

It is hard to distinguish a single distinct Madurese culture. Although the people in this book share similar cultural traits and a similar language, these break down into a large number of local variations. The language for instance divides into two language groups (West Madurese and East Madurese) and also has a large number of local dialects. The same is true with a number of visible cultural traits in which cattle play an important role, as well as the celurit, the crescent-shaped knife, local and religious (kiai) leadership, pesantren (Islamic boarding school) education and traditional Islam. The Madurese beyond Madura do not share a single culture, a single authority structure or a single indigenous legal system.

It are outsiders who identify them as a people with a strong perception of honour and pride, as hot-tempered, traditionally Islamic, but also as loyal, friendly and hospitable. Madurese themselves tend not to identify Madurese from mainland East Java as genuine Madurese, but rather as 'mixed' people (Retsikas 2007:189). Probably as a consequence of the widespread negative stereotyping and traumatic experiences in West and Central Kalimantan migration areas, they often prefer not to be identified as Madurese. Again, as this book shows, local variations dominate over universal traits. It is only in their homes, or back in East Java, where Madurese characteristics become visible and survive in music, arts, food habits, naval trade and agro-ecological and socio-cultural arrangements (Bouvier 2002, De Jonge 2012, Latief Wiyata 2002, Smith 2011, Stenross 2011). These cultural issues however were not the core 
focus of this study and have been studied extensively by others (Bouvier 2002, De Jonge 1990, 1993, 2012, Husson 1997b, Van Dijk et al. 1995).

Another pattern that emerges out of this book is that most Madurese have never established a constructive relationship with the state and largely miss out on its enormous powers of patronage. In the past, keeping the state at arm's length may have been a good strategy, but this may no longer be true in the new rapidly developing Indonesia. Among the existing relationships with the state are negative forms through corruption. The majority of the Madurese described in this book are disconnected from the bureaucratic and educational system, and lack the important connections that help access projects, income-earning opportunities and state-based social protection. This becomes especially clear when it comes to social welfare and social security. They have to organize their livelihood security and social welfare themselves through social means. Where is the Madurese middle class? Is that what is missing and does the lack of a brokering middleclass explain them seemingly forgotten or 'surplus' to the Indonesian economy?

Despite not faring as well as others, this does not mean that they have not benefited at all from the major developmental changes in Indonesia. Since 1997, large improvements have been made in Indonesia through road development, improved sanitation, electrification, credit opportunities (enabling the purchase of motorbikes), mobility and the introduction of village healthcare and education - albeit not always of good quality.

The Madurese in East Java have benefitted from these developments. Since the crisis years of 1997-2000, small rations of subsidized food for the poor (sembako, raskin) have become available to most poor villagers, as well as some financial support for disabled people. Access to medical care has improved through the introduction of basic health insurance, and emergency aid has become more available, as seen with the landslides in Krajan in 2003, a tornado in 2009 and the resettlement of Madurese displaced from Kalimantan between 2001 and 2005. Nevertheless, many of these interventions are incidental and focussed on minimal support for the poorest. They do not lead to social inclusion in the productive sectors of the mainstream economy.

Despite impressive national growth figures, making Indonesia a middleincome country, state social-security programmes are limited and unable to cover all the people in poor and remote villages such as Krajan in East Java and migrants in East Kalimantan. In the new Indonesia, the majority of Madurese, and the poor in general, have to rely on their own resources and on local forms of support.

The national developmental success of Indonesia has not led to continued rural development in the poor and remote villages of Java and Madura, in the 
sense of increased productive opportunities, higher incomes or the creation of wealth. On the contrary, the image from rural East Java is one of stagnation. In the villages, as described in Chapter 2, a process of ongoing differentiation is taking place with inequalities in social relations increasing among villagers. For many who stay put in the village, making a decent livelihood is impossible because land ownership is unequal and income-earning opportunities are few.

Migration opportunities offer a way out of poverty - although only a few Krajanese have ever been successful in the diaspora and returned with the hoped-for money. They seem to lack the skills, the capital and the networks to move to the more lucrative jobs in the Middle East or to Malaysia. Those who went to Malaysia could only travel the 'aspal route' (Cribb 2000:58, Ford and Lyons 2011), or illegally, and ended up in low paid, problematic jobs or in countries like Yemen (De Regt and Moors 2008).

Over the years, hundreds of men and women from the village of Krajan have tried their luck elsewhere - sometimes enforced by debts from gambling or risky investments, maybe spurred on by death threats, or simply lured into disadvantageous labour arrangements by middlemen and recruiters who promise work and a good income by riding the waves of economic opportunity. The large majority of these migrants end up in Kalimantan's construction sector, informal economy, brick kilns or oil palm plantations. Some are successful and return home, the majority simply 'vanish' and never come back or send any money. Enthusiastic or not, migration is the only option for many, but chances on success are low. As a result of agrarian differentiation and migration, "locally organized, village-based social security arrangements are coming under increasing pressure and are increasingly exclusivist' (Hüsken and Koning 2006:25).

\section{Historic Parallels}

For decades, Madurese have migrated in search of a better life. With improved transportation and communication, this migration has grown massively since 2001. Reliable figures on this undocumented migration between East Java and East Kalimantan is lacking and more research on this topic is needed. Contrary to many other migration waves in Indonesia, which flow to Indonesia's major cities and to the Middle East and Gulf countries, the poorly educated Madurese from mainland East Java head for rural areas in Kalimantan and to the unstable frontier areas that offer them a slightly better livelihood through access to low paid jobs in plantations, mines, quarries and in the construction industry. They are the labour force who occupy the ranks of a huge army of - often 


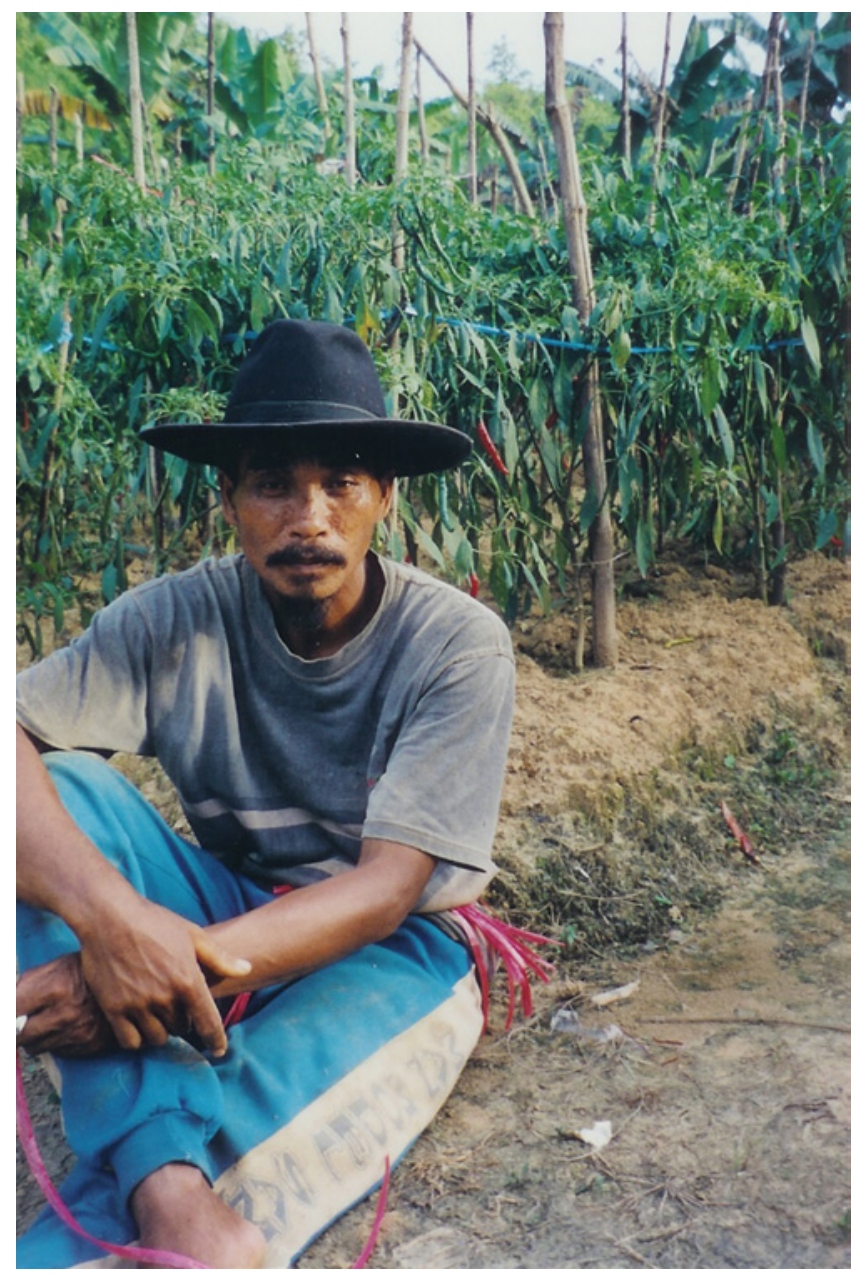

ILLUSTRATION 14 Successful farmer from Malang

unnoticed - people who make the Indonesian economic growth model - still dependend on the production and export of minerals and raw resources - possible. The threats of ethnic violence in Kalimantan have clearly not ended the Madurese search for work and income in Kalimantan -probably because there is no other option.

A historical comparison shows parallels between migration to Krajan in the 19th century and the contemporary migration of Madurese and Krajan people who settle in the frontier areas of Kalimantan. Historically, three waves of Madurese migration can be distinguished. The first, in the 18th and 19th centuries, being the early migration of people looking for land to mainland East Java. 
At the end of 19th century and the first half of the 2oth century, a second wave of migrants mobilized themselves to work as labourers in the agricultural commodity production and plantation economy of East Java serving the needs of cheap workers to produce commodities for the global market. Finally, since the mid-1970s, there was a wave of Madurese migrants to Kalimantan, initially looking for land, work and a job and increasingly to work as labourers in the oil palm plantations. Again to serve the needs of cheap commodity production for the global market.

Today's patterns of Madurese migration to rural Kalimantan are thus somewhat similar to the earlier waves of migration to East Java. Whereas East Java can be characterized as the Madurese homeland complete with established social and cultural agrarian practices (although the social life is not at all static and isolated); East Kalimatan is a dynamic frontier area directly connected to global commodity markets. In both places, if they are noticed at all, Madurese are seen as somewhat of a nuisance and their poverty as a threat to national security and the established livelihoods of urban middle classes and elites. Their role as reliable and cheap workers, who serve the production of global commodities, is largely left out of public discourse.

Due to difficulties in making a living and low education, since colonial times, many Madurese juggle their livelihoods in the grey area between legal and illegal, licit and illicit activities as described in the last chapter. Studying these activities and the relationships with the police or other state representatives in detail, it becomes clear that the state is as much dependent on them to secure income, order and security as migrants depend on the state for protection and recognition. It is maintaining these ambigious and intricate patrimonial relationships with lower ranked state officials which turn out crucial.

The history of Madurese migration to the uplands of East Java, of 'land-poor marginalized people creeping into upland spaces beyond control of valley states and lowland people' (Scott 2009:179), would be repeated in the 2oth century by Madurese occupying the frontier areas of Kalimantan. Whereas Scott interprets these processes as state evasion and as 'designed to position themselves vis-à-vis the valley states' (Scott 2009:179), the migration histories and interviews with recent settlers show rather that these processes are often driven by a thirst for empty land - although much of the land was probably never empty - and a hope of a better future. These processes cannot be understood as protests against the state, or as a reaction on processes of state making and cultural dominance in East Java. Rather, Madurese migration takes place despite the state and in accordance to long established nation state ideologies about nation making and unity in diversity. Thus, the waves of Madurese coming to Kalimantan today to work at the oil palm and rubber estates of the newly 
colonized plains of Kalimantan resemble the earlier waves which were enabled by the colonial government in the late 19th century and early 2oth century. Plantation owners continue to favour Madurese labourers, just as they did during colonial times: seeing them as cheap, hardworking, honest, disciplined, loyal and strong (De Jonge 1995:15).

\section{Poverty and Social Security}

People in rural East Java often told that social isolation was the largest problem of poverty. Isolated people have less access to information, employment, networks and systems of support and redistribution, all of which have the potential to offer some access to resources. A lack of resources, or access to resources, and being excluded from redistribution mechanisms such as social security arrangements make people much more vulnerable to contingencies in life than simply a lack of income. Being poor means being restricted and vulnerable in many respects: poor people face a wide range of limitations, and have fewer options and abilities for strategic action than their more prosperous fellow villagers.

The examples of people and families in this book show that the lives and living conditions of poor people are not stable, incomes cannot be taken for granted and social security entitlements can change relatively quickly. Over the course of one generation, families have fallen from relative wealth into poverty, while others were able to escape poverty. Class does not determine someone's future. Poverty and affluence are not fixed categories, and nor are kinship and other social ties that might offer protection. Wealth can diminish over the years, and friends or relatives can disappear or turn out to be unreliable partners. Sometimes only minor events or misfortunes are enough to trigger the downfall of a family, while others would receive support in similar circumstances. Conversely, with some luck, hard work and favourable conditions, some manage to rise above others, and establish a stronger livelihood or better support relationships. This book describes many such stories. Moreover, these stories are not unique, they could be the life histories of poor families all over Indonesia, families who are slowly rising, declining or cyclically crossing the poverty line.

The Satrawi family offers a good example of villagers who have invested in social relationships and mutual help, but who then failed to get back what they had invested (see Chapter 3). Organizing large weddings and rituals proved not to be a reliable strategy for insuring against severe livelihood setbacks. The problem is that, given their present poverty, people calculate that providing 
large contributions is not worthwhile as even the Satrawi children will probably never be in a position to repay them. As such, this reflects a situation where investments in local forms of social security tend to be 'upward looking' rather than 'downwardly protective'.

Many years ago, James Scott argued in his book 'The Moral Economy of the Peasant' (1976), that peasant societies in South East Asia can be characterized by two principles: (1) that peasants are risk-averse and oriented towards subsistence and reciprocity; and (2) that inequalities between peasants are not extreme and the 'moral economy' offers its members a certain 'right of subsistence' based on 'the norm of reciprocity' (Scott 1976:30). He argues that peasants have collectively developed risk-insurance subsistence mechanisms out of a shared moral norm which enable them survive the most difficult times and which provide the basis of local social security. This book shows that the relationships of mutual help and village social security are seldom enough to protect against the negative impact of poverty, social exclusion and the shocks and stresses in livelihoods.

A significant number of the population are effectively excluded from most exchanges and forms of support, and these are the people who most need support. It seems that those who need the most receive the least: the poorest villagers receive insufficient support and are unable to secure their welfare. These poor, who make up one-third of the Krajan population, need the support of village institutions but because they cannot contribute to them, and have poor networks, they face social exclusion from them. Moreover, even if they do manage to meet some of the social expectations, they pay relatively more than their richer neighbours and certainly more than they will ever receive back. The mid-level and richer categories of the local population get more out of village social welfare than they put in.

These paradoxes of local social security can be summarized as follows. Firstly, poorer villagers are more vulnerable to insecurities than richer villagers, and they have fewer means of protection. Poorer villagers pay relatively more (as a proportion of total income) for their funerals, rituals (selamatan) and weddings, while receiving less support and gifts (sumbangan) on these occasions because their networks are smaller and their friends and relatives are generally poorer. Secondly, poorer villagers who are engaged in mutual help and mutual labour groups generally donate more labour to their richer neighbours, due to their larger plots, than is reciprocated. Labour services given to richer village members, politicians, relatives and patrons are often seen as investments and premiums but, again, these generally cost more than the social security ever provided by these politicians, patrons and relatives. Moreover, their labour contributes to the prosperity of such patrons and thus 
sustains or increases the gap between rich and poor in rural Java. Those who most need credit can borrow least, and pay the highest interest rates. Clearly, the institutions, arrangements and social relationships in rural East Java are inadequate to overcome the 'insecurity trap' and it seems likely that this will remain the situation. These arrangements are even becoming more exclusionist: it is now the 'little-less-poor' who are excluding the 'poor'.

Even if such a subsistence ethic and its related village-levelling mechanisms, or collective support systems, did once exist - which is strongly doubted by several historians and anthropologists (Abdullah and White 2006, Hüsken and Koning 2006:18, Hüsken and White 1989, Popkin 1979, White 1983, 2000) - it seems highly unlikely that they would remain strong in present-day peasant societies which are increasingly incorporated into the global economy and closely linked to urban centres and national policies. This book concurs with the view that strong collective support systems in rural Indonesia are largely a myth (see Chapter 3). Rather, such ideas romanticize local communities as harmonious and sharing - and the question can be asked as to who is interested in maintaining these images and why are they maintained? The image of the romantic village also contributes to the blindly accepted beliefs of policymakers who often assume rural societies to be harmonious. It might serve to legitimize economic development policies which do not invest in peasant livelihoods and strengthening social safety nets. Maybe it also explains why the Indonesian government's social protection schemes in general still fail to reach the majority of the poor.

\section{Poverty and Risk}

From this study, one cannot conclude, as others have done, that poor people and poor migrants are inherently risk averse. On the contrary, many of the poor people described in this book consciously take huge risks, and also sometimes unconsciously. As described in Chapter 5 , deliberate risk-taking by the very poor seems to be a reaction to their limited prospects and dull and tied village lives. Some people no longer accept working every day for a small wage with no prospect of improvement and a better livelihood with fewer difficulties. Instead, some opt for thrills and the chance of success, even if this loses them their entitlement to minimum subsistence and involves a break with family members. However, maybe for some, this lifestyle is less risky than it first appears because gendered structures in the household and societal social relations will sometimes offer a minimal safety net as can be seen in Chapter 8. 
In looking at the examples in this book, and those who are taking risks in East Java and East Kalimantan, we see an association between certain people, households and risk-taking activities. Those willing to take huge risks in gambling, often also adopt a chancy style in their farming or trading, and they show great machismo. For this group of people, called orang nakal in East Java and in East Kalimantan, risk-taking is more than a livelihood strategy, it is rather a lifestyle in itself. In Kalimantan, taking huge risks might be the only way out for migrants. While it is generally held that people only take risks when their basic means are secured, and that people seek a favourable mix of security and risk, many of the orang nakal are poor and combine risks with other risks. Combining gambling and illicit sexual affairs is not uncommon; although not all gamblers are promiscuous, and not all womanizers are gamblers or take huge risks in other aspects of their lives. Other combinations are also frequent, such as gambling and sudden migration, reckless business investments and heavy borrowing.

Madurese migrant entrepreneurs in East Kalimantan face numerous obstacles in making their enterprises work. Brickmakers face difficulties in obtaining land rights and cheap firewood. Transport entrepreneurs face insecurities in obtaining transport licences. Workers in the stone quarries need protection against exploitative middlemen and insecure contracts. Moreover, Madurese migrants are not among the most-favoured ethnic groups in East Kalimantan and sometimes face discrimination and severe hostility. This is not always without good reason as some Madurese migrants are, or have been, involved in illegal and illicit activities such as organizing cockfights, gambling, theft, gang fights and running prostitution rackets. Madurese entrepreneurs and preman involved in such illegal activities find it essential to maintain good relationships with police officers, and generally with low-ranking ones, for protection and to keep their activities running. They maintain these relationships with police officers through regular visits and payments of either irregular sums or fixed shares of the profits generated from the business.

\section{Social Security in the Migration Areas}

Many of the village-based forms of social security, described in the first part of the book, that are to be found in the villages of East Java do not exist in the migration areas studied. In these locations, the Madurese live among other ethnic groups and do not form or maintain the community- and membershipbased arrangements seen in East Java. Neither do they create new forms that cross ethnic lines. Arrangements that I did not find in East Kalimantan include 
collective house-building (gotong royong), massive funerals attended by the full neighbourhood, large selamatan - and thus also no systems of reciprocal gift giving (sumbangan), rotating labour groups and assistance (giliran and keajegan Mad.), arisan, share-raising of cattle (oanan Mad., mengubu Mad.) and harvest shares (babun Mad.). These arrangements are very dependent on community solidarity and specific modes of production that do not exist in the migration areas.

This does not mean that there is no social safety net among Madurese migrants. Ones found are much more based on kinship and ethnicity. Social security in migration areas is limited to close kin (siblings, uncles and aunts, and nephews and nieces), to among neighbours who left together and now live close by and to fellow workers, for instance in brick kilns. Kinship is the prime locus of support, and even more important than in East Java. Relatives help each other out with small loans to provide care and protection, for business development, in the event of hospitalization, when in trouble with authorities or neighbours and with coping with all kind of daily troubles. However, with the exception of brickmaking entrepreneurs, this help is not extended beyond kin. These entrepreneurs almost all come from the village of Geger, in Bangkalan Madura, and they are prepared to help non-kin with business loans, loans in the event of an emergency, with labour when firing bricks and collecting firewood, and when political tensions occur.

In all the migrants groups studied, patronage was to be found within employer - labourer relationships and sometimes among creditors and borrowers, within family clans and also among religious and strong leaders, such as kiai and gang leaders, and their followers. Occasionally, non-Madurese people would act as a patron, such as in the described cases of policemen offering business protection, Chinese employers who employ Madurese as security guards, and rich neighbours who provide land and protection in return for a large share of the business profit.

From this, one can conclude that, contrary to a persistent stereotype, Madurese do not form close communities offering support and protection to each other. In reality, the perceived Madurese society in Samarinda is actually several highly stratified clusters based on kinship and/or shared roots that often compete with each other. When a crisis occurs, it is everyman for himself.

When it comes to sending remittances home, two patterns can be seen. In the case of migrants from Bangkalan, money was regularly sent home to support parents, children and close relatives for purposes such as care, house construction and the education of siblings, nephews and nieces. This seldom occurred In the case of migrants from mainland East Java and specifically 
Krajan. This might be linked to the relatively prosperous position of the Bangkalan migrants, and the fact that they migrated earlier and were able to establish a more stable business or enterprise. Generally, poor labourers seldom send money home, they can only aim to save a little from their meagre incomes and return with some money to be spent on household needs or specific purposes such as paying off debts or contributing to a marriage or a selamatan. Only those few migrants who have been able to establish a stable livelihood, a business or good trade with regular incomes are able to regularly send money home to support parents, siblings or children. To date few Krajanese migrants have been able to establish such a stable livelihood.

If local social security institutions and arrangements work at all, they generally seem to only cover specific risks and uncertainties, to be accessible only to certain groups and categories of people, and only to be tapped in specific circumstances or periods (Hüsken and Koning 2006:18). In Chapter 3 of this book, the scope and limitations of local forms of social security are described in detail. These limits mean that people are often excluded from such collective or communal provisions and that, therefore, they have to rely on their own devices, relations and inventiveness. Essentially, the poorer you are and the most support you need, the less you are protected. Will this remain reality for the majority of the poor and the Madurese in the new Indonesia? 